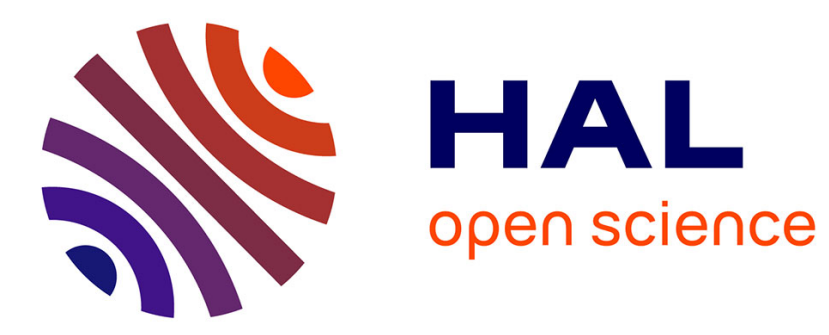

\title{
Technical Efficiency and ICT Investment in Italian Manufacturing Firms
}

\author{
Concetta Castiglione
}

\section{To cite this version:}

Concetta Castiglione. Technical Efficiency and ICT Investment in Italian Manufacturing Firms. Applied Economics, 2011, pp.1. 10.1080/00036846.2011.554374 . hal-00682262

\section{HAL Id: hal-00682262 \\ https://hal.science/hal-00682262}

Submitted on 24 Mar 2012

HAL is a multi-disciplinary open access archive for the deposit and dissemination of scientific research documents, whether they are published or not. The documents may come from teaching and research institutions in France or abroad, or from public or private research centers.
L'archive ouverte pluridisciplinaire HAL, est destinée au dépôt et à la diffusion de documents scientifiques de niveau recherche, publiés ou non, émanant des établissements d'enseignement et de recherche français ou étrangers, des laboratoires publics ou privés. 


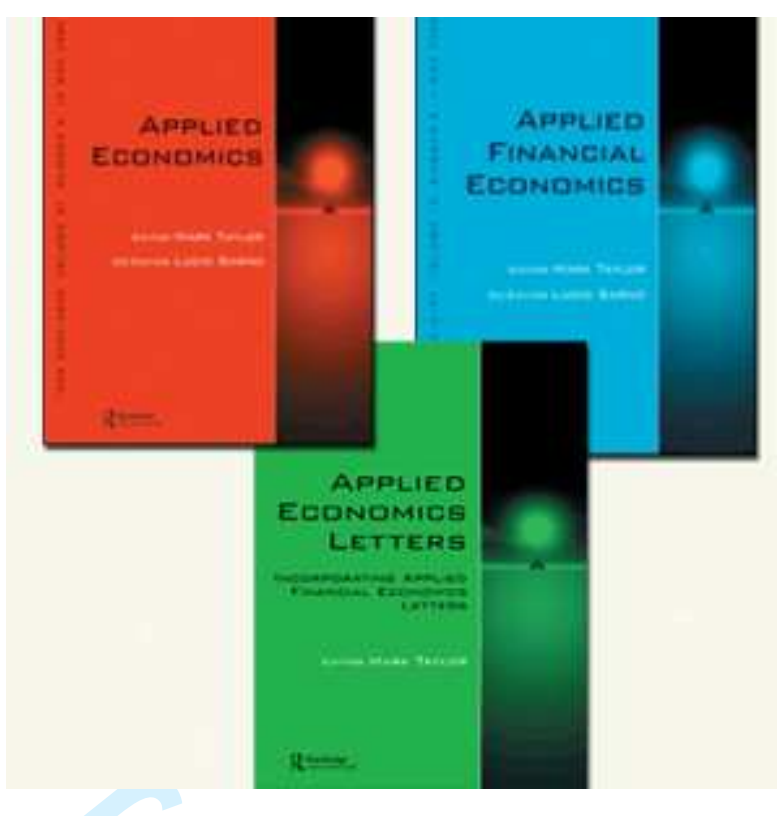

\section{Technical Efficiency and ICT Investment in Italian Manufacturing Firms}

\begin{tabular}{|c|c|}
\hline Journal: & Applied Economics \\
\hline Manuscript ID: & APE-2009-0232.R1 \\
\hline Journal Selection: & Applied Economics \\
\hline $\begin{array}{r}\text { Date Submitted by the } \\
\text { Author: }\end{array}$ & 03-Mar-2010 \\
\hline Complete List of Authors: & Castiglione, Concetta; Trinity College Dublin, Economics \\
\hline JEL Code: & $\begin{array}{l}\text { D21 - Firm Behavior }<\text { D2 - Production and Organizations }<\text { D - } \\
\text { Microeconomics, L63 - Microelectronics } \mid \text { Computers } \mid \text { Communications } \\
\text { Equipment }<\mathrm{L} 6-\text { Industry Studies: Manufacturing }<\mathrm{L} \text { - Industrial } \\
\text { Organization, O33 - Technological Change: Choices and } \\
\text { Consequences } \mid \text { Diffusion Processes }<03-\text { Technological } \\
\text { Change|Research and Development }<0 \text { - Economic Development, } \\
\text { Technological Change, and Growth }\end{array}$ \\
\hline Keywords: & $\begin{array}{l}\text { ICT investment, Productivity, Stochastic frontier, Italian } \\
\text { manufacturing firms }\end{array}$ \\
\hline
\end{tabular}




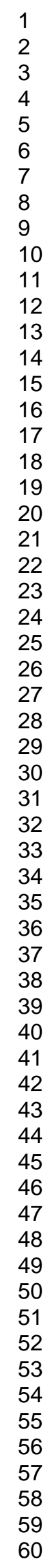

\section{S) ScholaroNE" \\ Manuscript Central}




\title{
ICT Investment and Firm Technical Efficiency \\ $\underline{\text { Technical Efficiency and ICT Investment in Italian Manufacturing }}$ \\ firms
}

\author{
Concetta Castiglione \\ Department of Economics, Arts Building, Trinity College, Dublin 2, Ireland \\ E-mail: castiglc@tcd.ie
}

Running title: ICT and firm technical efficiency

\begin{abstract}
The importance of information and communication technologies (ICTs) is a much debated question with extensive literature aimed at understanding the role of ICTs in increasing economic growth, firm productivity and firm efficiency. Different methods to estimate firm efficiency are used in this study. In particular, both the translog and the Cobb-Douglas production functions are used in order to estimate the impact of information and communication technology on technical efficiency (TE) in Italian manufacturing firms over the period 1995-2003. Results show that ICT investments positively and significantly affected firms' technical efficiency. Moreover, group, size and geographical position have a positive influence on TE. Finally, the results show that older firms are, on average, more efficient than newer ones.
\end{abstract}

Editorial Office, Dept of Economics, Warwick University, Coventry CV4 7AL, UK 


\section{Introduction}

The influence of information and communication technology (ICT) is a topic that has received increased attention from economists over the past two decades, its impact on economic growth being the subject of numerous studies at both aggregate and firm levels (Brynjolfsson and Hitt, 1996; Gordon, 2000; Oliner and Sichel, 2000).

During the 1980s and early 1990s many researchers asserted that the contribution of ICT to productivity and economic growth was either very small or non-existent (Gilchrist et al, 2001). These findings are often associated with the Solow paradox, which states that: "You can see the computer age everywhere but in the productivity statistics". Nevertheless, the latest studies increasingly assert the importance of new technologies.

The empirical literature focuses on the relationship between ICT investments and labour productivity or ICT investments and Total Factor Productivity (TFP). Some attempts have been made to study the relationship between ICT investments and technical efficiency (TE) at firm level (Assefa and Matambalya, 2002; Becchetti et al., 2003; Gholami et al., 2004 and Shao and Lin, 2001; 2002).

This work starts by over-viewing the previous literature and moves in two directions. Firstly, two different production functions, Cobb-Douglas and Translog, are used to explore investments and the average distance of producers from the "best practice"' by using a stochastic frontier approach. Both production functions are used since the Cobb-Douglas requires the elasticity of substitution between factors to be unity while the translog production function is a generalization of the Cobb-Douglas which relaxes this restriction. Secondly, ICT 
technologies are considered as a factor which is able to influence technical efficiency.

In this work, the impact of ICT technologies on technical efficiency is analysed under the hypothesis that a greater use of ICT at firm and economy level may help firms to increase their efficiency. The purpose of this work is to investigate whether ICT investments significantly affect a firm's distance from the optimal production frontier. In order to test this hypothesis, the stochastic frontier production function is adopted utilising an unbalanced panel data of Italian manufacturing firms elaborated from the results of the VII, VIII and IX surveys carried out by Mediocredito Centrale-Capitalia (MCC). Other works use the same surveys (VII or VIII) to study the relationship between ICT investments and productivity growth (Atzeni and Carboni, 2001; Bugamelli and Pagane, 2004), total factor productivity growth (Gambardella and Torrisi, 2001) or technical efficiency (Becchettiet al., 2003).

Our results show that ICT investments have a positive effect on the technical efficiency of Italian manufacturing firms when ICT is considered to be a firm specific factor.

The remainder of this paper is structured as follows: the first section focuses on the productivity paradox from a historical context and on the ICT contribution to economic growth. The second section presents the methodology, which encompasses the economic model and the empirical approach in order to evaluate the relationship between ICT and distance from the "efficient frontier", and describes the data used. To conclude, results and comments are presented. 


\section{Theoretical background}

Robert Solow's (1987) assertion that "You can see the computer age everywhere but in the productivity statistics" is still the object of much investigation, although the latest studies increasingly assert the importance of new technologies. In fact, recent productivity and GDP growth has been mainly related to the impact of information and communication technology investments.

Many economists describe this controversy as "the productivity paradox". The idea of this paradox emerged in the late 1980s when it was questioned whether ICT delivered its promised returns in increasing productivity. However, this paradox no longer seemed to be relevant after Brynjolfsson and Hitt (1996) presented their significant firm-level empirical evidence suggesting that the paradox had become a thing of the past by the beginning of the1990s.

Today, the importance of new technologies can be observed in many studies, both in theoretical and applied economics. In fact, over the past twenty years the impact of ICT on economic growth has been the subject of numerous studies at different levels: i.e. firms, industries and countries (Jorgenson, 2001; Oliner and Sichel, 2000).

Gordon (2000, 2002), who expressed different conclusions in the past, now affirms that ICT investments contribute more than other technologies to economic growth. Moreover, more than ten years after the statement of the paradox, Solow himself admitted that the statistics were beginning to measure the influence of the computer age, albeit still modestly at the moment ${ }^{1}$. There is now persuasive evidence that the boom in information and communication technology

\footnotetext{
${ }^{1}$ Solow is quoted as such in Gordon (2002)
} 
investments of the 1990s has led to significant changes in the absolute and relative productivity performance of firms, sectors and countries. For example, at the microeconomic level, Brynjolfsson and Hitt (2000) and Gilchrist et al. (2001) show that the payoffs to ICT investments occur not just in labour productivity but also in total factor productivity.

\section{HCT contribution to economic growth}

Empirical analysis of economic growth and productivity typically distinguishes three effects of ICT (Kenneth et al., 1994; Pilat, 2004). First, the "production effect": the firms producing these technologies can help economic growth at an aggregate level, either through a rapid increase in demand for these products compared with other sectors or through a higher level of productivity in the same sector. In fact, technological progress in the production of ICT goods directly raises total factor productivity in ICT producing industries.

The second is the "using effect": firms in traditional sectors increase capital stock per worker (capital deepening) in order to acquire new technologies, this implies an increase in output per worker. Engelbrecht and Xayavong (2005) assert that the fall in ICT capital prices with respect to those of other types of capital encourages firms to substitute the former for the latter. In this way, an increase in investment in ICT capital contributes to labour productivity growth in ICT using industries through capital deepening effects. Schreyer (2000) points out that substitution processes are an important element in assessing the role of ICT in production. This approach treats ICT capital goods like all other types of capital goods. In particular, it is assumed that firms which own ICT assets are able to 
reap most or all of the benefits that accrue from using new technologies. Moreover, a greater use of ICT throughout the economy may help firms to increase their overall efficiency.

Furthermore, greater use of ICT may contribute to network effects, such as lower transaction costs and more rapid innovation, which should also improve TFP. In fact, the third effect of ICT is "total factor productivity": the adopting of new technology improves the performance of all the factors used. Consequently, output increases without further input investment. An increase in total factor productivity means that, at a given input level and a fixed quality, an economy always obtains higher output levels (Castiglione, 2008).

Finally, many other authors suggest that ICT generates a fourth effect in the form of spillovers through efficiency gains in the production process, and through the accumulation of intangible organizational capital accompanying investment in ICT capital (Stireh, 2000; Basu et al., 2003). Such positive externalities, or spillover effects, may accelerate TFP growth in ICT using industries.

In this work ICTs are considered as General Purpose Technologies (GPTs) i.e. fundamental technological innovations that are characterised by pervasiveness, technological dynamism and innovative complementarities. The technological dynamism characteristic indicates continuous efforts at innovation, as well as learning, increasing over time the efficiency with which the generic function is performed (Bresnahan and Trajtenberg, 1995). This should show up as a reduction in prices, an increase in quality, or both. The improvement a GPT brings about can therefore be measured in terms of how much cheaper a unit of quality becomes over time. If technology is embodied in capital, then presumably capital 
as a whole should become cheaper and faster during a GPT period, especially capital which is tied to the new technology.

During the GPT phase, technological progress could be separated into two dimensions. One would be a new technological paradigm (i.e. steam engine or electricity) and the other would be an increasing number of innovations within the paradigm. With the two different types of technological progress the production function is shifted up.

Helpman and Trajtenberg (1996) assert that each time a new GPT appears, it generates a cycle consisting of two distinct phases. During the first phase resources are diverted to the development of complementary inputs permitting exploitation of the new GPT. Output and productivity experience negative growth and the real wage stagnates. In the second phase, after enough complementary inputs have been developed, old inputs are replaced by the more productive GPT. During this phase output, real wages and profits increase.

In this way it is possible also to explain the productivity paradox. In fact, from the study by Jovanovic and Rousseau (2005), it is possible to assert that the slowing down of productivity during the ICT period could be explained as a learning phase, but when investments in new technologies increase productivity should rapidly increase (Castiglione, 2006).

\section{III.Stochastic frontier approach}

We assume that ICT are GPT because, according to Bresnahan and Trajtenberg (1995), they open the road to new opportunities for existing technologies too, improving the performances of all the factors used. To verify this hypothesis the 
contribution of ICT investment to firm productivity is explored empirically using a stochastic production frontier approach. The production frontier, which characterises the relationship between inputs and output, specifies the maximum output achievable by employing a combination of inputs. The distance between the production frontier and the actual output is regarded as the firm's technical inefficiency. Thus, a firm either operates below the frontier when it is technically inefficient or it operates on the production frontier when it is technically efficient.

The concept of TE was elaborated by Farrell (1957) who stated that the efficiency of a firm consists of two components: technical efficiency and allocative efficiency. TE is concerned with the maximisation of output for a given set of resource inputs and indicates the ability of a firm to obtain maximum output from a given set of inputs. Allocative efficiency reflects the firm's ability to use inputs in optimal proportions, given their respective price and the production technology. Jha et al. (1998) use Data Envelopment Analysis (DEA) in order to measure both technical and allocative efficiency in Indian firms. Together technical and allocative efficiency provide a measure of total economic efficiency.

According to Battese and Coelli (1995) productivity growth from one year to the next can be the result either of efficiency improvements or to technical change. Fig. 1 shows a typical production frontier, $S F$, with one input $x$ and one output $y$. Technical change may be represented by an upward shift in the production frontier. This is depicted in Fig. 1 by the movement in the production frontier from $S F_{\text {NICT }}$ to $S F_{I C T}$.

With the new, higher production frontier all firms may technically produce more output for each level of input, compared with what was possible with the 
lower production frontier. In our work, technical change is represented by investments in ICT; the first production frontier $S F_{N I C T}$ regards those firms which do not invest in ICT whilst the second regards firms investing in ICT.

Suppose a firm operates at point $A$. According to the production frontier, the firm might increase its output level to point $B$ if it does not invest in ICT and to point $B^{\prime}$ if it does invest in ICT, using the same input $X_{1}$, and, hence, the distance $A B^{\prime}$ can be regarded as the firm's technical inefficiency. In fact, a firm operating at point $A$ is inefficient because technically it could increase output to the level associated with point $B$ or $B^{\prime}$ with no extra input or, alternatively, it could produce the same level of output using less input: producing at point $D$ or $D^{\prime}$ on the frontier.

\section{[Insert Figure 1 about here]}

Hence inefficiency may be divided into two parts: technical inefficiency (from $A$ to $B$ ) and the additional inefficiency due to the ICT gap (from $B$ to $B^{\prime}$ ).

Another definition of $\mathrm{TE}$ is the ratio $A B^{\prime} / B^{\prime} C$ representing technical inefficiency and $A C / B^{\prime} C\left(=1-A B^{\prime} / B^{\prime} C\right)$ representing TE. On the other hand, in terms of the inefficiency due to the ICT gap, we can write: $\mathrm{AB} / \mathrm{BC}$ for technical inefficiency and $\mathrm{AC} / \mathrm{BC}(=1-\mathrm{AB} / \mathrm{BC})$ to represent technical efficiency. "One advantage of these ratio measures for technical efficiency is that they are unit invariant; i.e. changing the units of measurements does not change the scores of efficiency measurement. This ratio of technical efficiency will take on a value between zero and one, with a higher score implying higher technical efficiency" (Shao and Lin, 2001: 448). A technically inefficient firm could produce the same 
output with at least one input fewer or could use the same input to produce at least ene output more.

The measurement of technical efficiency has widely been associated with the use of production frontier functions. As Arestis (2006) pointed out traditional $\underline{\text { econometric estimation techniques (such as ordinary least squares) fail to measure }}$ a production frontier, because they allow some of the observed output bundles produced by a given set of inputs to be greater than the estimated maximal producible output. Albert (1998) suggests to estimate an idealized production frontier (best-practice frontier) in which "efficient agents can be localized and the deviations of all other firms from this frontier (inefficiencies) can be calculated." (Albert, 1998: 723).

Several techniques to determine these frontier functions have been used: parametric and non-parametric. The choice of estimation method has been a subject of debate (Seiford, 1996) since every method has its advantages and disadvantages. The principal advantage of the estimation of a non-parametric production frontier, using for example the data envelopment analysis (DEA) technique, is that it does not require any assumptions regarding the functional form. Also DEA does not require an explicit assumption about the inefficiency term (Odeck, 2007; Shao and Lin, 2002). However, using this kind of technique, it is not possible to distinguish whether the lack of efficiency is due to technical inefficiency or to statistical noise (Odeck, 2007: 2618).

The parametric approach requires the assumption of a specific functional form (e.g. Cobb-Douglas, translog, constant elasticity of substitution - CES) for the technology (constant or variable returns to scale) and an explicit distributional 
assumption for the inefficiency term. It uses econometric techniques to estimate the coefficients of the production function as well as the technical efficiency. The main strengths are that the parametric approach deals with stochastic noise and also allows statistical tests of hypotheses concerning production structure and the degree of inefficiency. The first step in parametric stochastic frontier estimation is, then, to select an appropriate functional form for the production function.

A number of studies (Carroll et al., 2007; Gholami et al., 2004 and Shao and Lin, 2001) have estimated both the Cobb-Douglas and the translog functional form and some of them (Carroll et al., 2007) have tested the null hypothesis that the Cobb-Douglas form is an adequate representation of the data, given the specification of the translog model.

\section{Cobb-Douglas and translog production frontier}

The Cobb-Douglas production frontier has been one of the most frequently used functional specifications in research on production economics. It satisfies the basic requirements for production frontiers, such as quasi-concavity and monotonicity. It imposes properties upon the production structure such as fixed returns to scale and an elasticity of substitution which is equal to unity.

The Cobb-Douglas stochastic production frontier with two inputs, capital $(K)$ and labour $(L)$, and one output $(Y)$ can be specified as:

$$
Y_{i}=\alpha K_{i}^{\beta_{k}} L_{i}^{\beta_{L}} e^{v_{i}-u_{i}}
$$

where $i$ is the index which considers the number of firms. After taking the natural logarithm, the production function can be rewritten in the following way: 


$$
\ln \left(Y_{i}\right)=\beta_{0}+\beta_{K} \ln K_{i}+\beta_{L} \ln L_{i}+v_{i}-u_{i}
$$

The random error $v_{i}$ is assumed to be independent and identically distributed (i.i.d.) with zero mean and constant variance $N\left(0, \sigma_{v}^{2}\right)$.

On the other hand, the residual component $u_{i}$ of technical inefficiency represents the effects of events incurred by the firm. These technical inefficiencies are assumed to be non-negative random variables of independently, but not identically distributed, truncated normal distributions. The underlying normal distribution is assumed to be $N\left(\mu_{i}, \sigma_{\mu}^{2}\right)$. TE is predicted using the conditional expectation of $\exp \left(-U_{i}\right)$, given the composed error term of the stochastic frontier.

Technical efficiency equals one only when a firm has an inefficiency effect equal to zero; otherwise it is less than one. If $U_{i}$ is equal to zero, this means that there is no inefficiency in production, the firm is technically efficient and produces its maximum potential output. Conversely, when $U_{i}$ has values lower than zero this implies that there is inefficiency in the firm's production and it produces less than its maximum possible output given the technology. The magnitude of $U_{i}$ measures the "efficiency gap", that is how far a given firm's output is from its potential output. In order to compute TE it is, therefore, necessary to estimate across potential output which can be achieved by the econometric estimation of the stochastic frontier production function.

A number of alternative functional forms have also been used in production frontier literature. The most popular is the translog function.

The two input, translog, stochastic production frontier can be specified in the following way: 
$\ln \left(Y_{i}\right)=\beta_{0}+\beta_{K} \ln K_{i}+\beta_{L} \ln L_{i}+\frac{1}{2}\left[\beta_{K K}\left(\ln K_{i}\right)^{2}+\beta_{L L}\left(\ln L_{i}\right)^{2}\right]+\beta_{K L} \ln K_{i} \ln L_{i}+v_{i}-u_{i}$

The assumptions about the random error $v_{i}$ and the technical efficiency $u_{i}$ remain the same as in the Cobb-Douglas stochastic production frontier.

The translog function does not impose the same restrictions upon the production structure as the Cobb-Douglas production function, but it may suffer from degrees of freedom and multicollinearity problems. However, the CobbDouglas stochastic production frontier is a special case of the translog stochastic production frontier under the following restrictions:

$$
\beta_{K K}=\beta_{K K}=\beta_{K L}=0
$$

The translog function is non-homogeneous and belongs to the class of flexible functional forms, which provides a second-order local approximation to any functional form (Coelli et al., 1998).

\section{Stochastic frontier for panel data}

Panel data models have some advantages over cross-sectional data in the estimation of stochastic frontier models. Schmidt and Sickles (1984) assert that the first advantage is that, while cross-section models assume that the inefficiency term and the input levels are independent, for panel data estimations this hypothesis is not needed. This is useful in order to introduce time-invariant regressors into the specification of the model. Moreover, by adding a temporal dimension to the observed unit data, panel data stochastic frontier models yield consistent estimates of the inefficiency term. Furthermore, by exploiting the link between the "one-sided inefficiency term" and the "firm effect" concepts, 
Schmidt and Sickles (1984) observed that, when panel data are available, there is no need for any distribution assumption for the inefficiency effect and all the relevant parameters of the frontier technology can be obtained by simply using the traditional estimation procedures for panel data; i.e. fixed-effects model and random-effects model approaches. Finally, panel data permit the simultaneous investigation of both technical change and technical efficiency change over time.

The panel data stochastic frontier models can be written in the following way:

$$
Y_{i t}=\beta_{0}+\sum_{n=1}^{N} \beta_{n} X_{n i t}+v_{i t}-u_{i t}, \quad i=1,2, \ldots, N ; \quad t=1,2, \ldots, T
$$

where $Y_{i t}$ denotes the output for the $i^{\text {th }}$ firm at the $t^{\text {th }}$ time period, $X_{i t}$ denotes a (1xk) vector of inputs associated with the suitable functional form, $\beta$ is a $(\mathrm{kx} 1)$ vector, to be estimated, of unknown scalar parameters, $u_{i t}$ are the inefficiency effects in the model and $v_{i t}$ are random errors, assumed to be i.i.d. and have $N\left(0, \sigma_{v}^{2}\right)$ distribution, independent of $u_{i t}$.

Sometimes it is assumed that technical inefficiency effects are time invariant:

$$
u_{i t}=u_{i} \quad i=1,2, \ldots, N ; \quad t=1,2, \ldots, T .
$$

"The assumption that technical inefficiency effects are time-invariant is more difficult to justify as $\mathrm{T}$ becomes larger. One would expect that managers learn from their previous experience in the production process and so their technical inefficiency effects would change in some persistent pattern over time" (Battese and Coelli, 1995: 203).

The model proposed by Battese and Coelli (1995) specifies technical inefficiency effects in the stochastic frontier model that are assumed to be independently (but not identically) distributed non-negative random variables. For 
the $i^{\text {th }}$ firm in the $t^{\text {th }}$ period, the technical inefficiency effect, $u_{i t}$, is obtained by a truncation of the $N\left(\mu_{i t}, \sigma^{2}\right)$ distribution, where $u_{i t}=z_{i t} \delta$. In this case $z_{i t}$ is a $(1 \mathrm{xM})$ vector of observable explanatory variables, whose values are fixed constants; and $\delta$ is a $(\mathrm{Mx} 1)$ vector, to be estimated, of unknown scalar parameters.

The log-likelihood function of this model is described in Battese and Coelli (1992) where $\sigma_{s}^{2}=\sigma_{v}^{2}+\sigma^{2}$ and $\gamma=\sigma^{2} / \sigma_{s}^{2}$, with $\gamma$-parameter values between zero and one.

\section{Economic model and empirical approach}

The main purpose of this work is to investigate whether ICT investments significantly affect a firm's distance from the optimal production frontier. Using the stochastic frontier approach, the inefficiency effects are expressed as an explicit function of a vector of firm-specific variables and a random error. This approach has been widely recognised to be better than the two-stage estimation procedure which assumes independence of the inefficiency effects. The two-stage estimation procedure is unlikely to provide estimates which are as efficient as those that could be obtained using a single-stage estimation procedure (Becchetti et al., 2003).

The empirical analysis is based on the following hypothesis: ICT investment has a positive effect on technical efficiency in the production process. In order to test this hypothesis the stochastic frontier production function (Cobb-Douglas and translog) is used. To estimate firm efficiency, it is important to include all possible inputs in the production function, because omission of one of the input 
factors may give a relatively higher efficiency to a firm which is using a greater quantity of these inputs. If this happens, two firms which, ceteris paribus, produce the same output may be located at the same point (e.g.: point $B$ in fig. 1 ) on the production frontier, while, in reality, the one that uses a greater quantity of the non included input, lies at a lower point (e.g.: point $A$ in fig. 1), because it is less efficient (Infante, 1990).

Following Becchetti et al. (2003) and Assefa and Matambalya (2002), raw materials are considered along with labour and capital as inputs in the production function. So, the Cobb-Douglas production model takes the following form:

$$
Y_{i t}=\alpha K_{i t}^{\beta_{1}} L_{i t}^{\beta_{2}} R M_{i t}^{\beta_{3}} e^{v_{i t}-u_{i t}} .
$$

After taking the natural logarithm and adding a set of dummy variables (i.e. three for the four Pavitt sectors ${ }^{2}$, and two for the three time periods ${ }^{3}$ ) the equation becomes:

$$
\ln \left(Y_{i t}\right)=\beta_{0}+\beta_{1} \ln K_{i t}+\beta_{2} \ln L_{i t}+\beta_{3} \ln R M_{i t}+\sum_{j=1}^{m-1} \alpha_{j} * P a v_{i j t}+\sum_{t=1}^{T} \alpha_{i} D_{i t}+v_{i t}-u_{i t}
$$

where $Y_{i t}$ is the real output of the $i^{\text {th }}$ firm at time $\mathrm{t}(i=1,2, \ldots, N$ and $t=1,2, \ldots T) ; K$ is the capital, $L$ the labour, $R M$ the raw materials and $P a v$ and $D$ are, respectively, the dummy variables for Pavitt sector and time period.

As indicated, the Cobb-Douglas production frontier imposes some restrictions, such as fixed returns to scale and unitary elasticity of substitution, on production technology. Hence, it is tested against the translog functional form. The translog

\footnotetext{
2 In the Pavitt taxonomy the sectors are classified in the following way: supplier dominated (Pavitt 1), scale intensive (Pavitt 2), specialised supplier (Pavitt 3) and science based (Pavitt 4).

3 The three periods are: 1995-1997, 1998-2000 and 2001-2003.
} 
stochastic production frontier with three inputs (capital, labour and raw materials) can be specified as:

$$
\begin{aligned}
\ln \left(Y_{i}\right)= & \beta_{0}+\beta_{1} \ln K_{i t}+\beta_{2} \ln L_{i t}+\beta_{3} \ln R M_{i t}+\beta_{4} \frac{\left(\ln K_{i t}\right)^{2}}{2}+\beta_{5} \frac{\left(\ln L_{i t}\right)^{2}}{2}+ \\
& +\beta_{6} \frac{\left(\ln R M_{i t}\right)^{2}}{2}+\beta_{7} \ln K_{i t} \ln L_{i t}+\beta_{8} \ln K_{i t} \ln R M_{i t}+\beta_{9} \ln L_{i t} \ln R M_{i t}+ \\
& +\sum_{j=1}^{m-1} \alpha_{j} * P a v_{i j t}+\sum_{t=1}^{T} \alpha_{t} D_{i t}+v_{i t}-u_{i t}
\end{aligned}
$$

To estimate the model a second set of independent variables is required and they are assumed to affect the level of efficiency at which manufacturing firms convert factors of production into output. The first variable is ICT investments since it is assumed that they are able to influence technical (in)efficiency. For the other variables, the theory does not point to any specific factor that should be included "it is more of an empirical question. As such, variables are selected on the basis of economic intuition" (Carroll et al., 2007: 6).

In this work ICT investment, age, firms affiliated to corporate firm, size of firm, geographic macroarea, Pavitt sectors and time period are considered as explicative firm efficiency variables. So, the inefficiency equation, in both cases (Cobb-Douglas and translog production frontier), is:

$$
\begin{aligned}
u_{i t}= & \alpha_{0}+\delta_{1} I C T_{i t}+\delta_{2} \text { age }_{i t}+\delta_{3} \text { group }_{i t}+\sum_{j=1}^{m-1} \alpha_{j} * \operatorname{size}_{i j t}+\sum_{s=1}^{n-1} \alpha_{s} * \text { Area }_{i s t}+\sum_{\gamma=1}^{n-1} \alpha_{\gamma} * P a v_{i \gamma t} \\
& +\sum_{t=1}^{T-1} \alpha_{t} D_{i t}+\varepsilon_{i t}
\end{aligned}
$$

where ICT represents investments in information and communication technology, group indicates whether a firm is affiliated to a corporate firm, size is the size of the firm (small if the firm has 11-50 employees, medium if the firm has 51-250 employees; large if the firm has more than 250 employees) and Area, Pav, and D 
indicate, respectively, the dummy variables for the Italian macro-territorial area, Pavitt sectors and time.

The empirical evidence of the impact of ICT on firm performance is mixed. In fact, in developed countries, the growth of total factor productivity associated with technical change has even declined with the increased use of ICT of the past 10 to 20 years (Jorgenson and Stiroh, 1999). It was only in the 1990s that empirical evidence showed that ICT has a substantial effect on firm productivity levels. Therefore, in this model, ICT investments have been included in order to understand whether there is a positive relationship between technical efficiency and ICT investments. Consequently, if the coefficient estimates for $\delta_{1}$ is significantly negative, there is empirical evidence to confirm that ICT has a favourable effect on technical efficiency.

The expected signs for all estimated beta parameters in the Cobb-Douglas production frontier and the elasticities in the translog production frontier are positive since each factor contributes to production positively. For delta parameters, the economic literature is used to hypothesise about the expected sign.

A positive relationship between age and technical efficiency can be expected due to "learning by doing" which occurs through production experience. Over time, firms become more efficient as a result of a growing stock of experience in the production process. However, other economists argue that when an innovation is introduced, newer firms generally adopt it easily, while older firms may have to delay adoption as it may be too costly to substitute old methods, thus implying that efficiency may decrease with age (Assefa and Matambalya, 2002). Empirical studies also report mixed results regarding the relationship between a firm's age 
and technical efficiency. Assefa and Matambalya (2002) assert that some studies have found a positive relationship between firm age and efficiency, other studies have reported a negative relationship between firm efficiency and age; while, some other studies have indicated that the effect of age could be neutral (Cheng and Tang, 1987).

The relationship between firms affiliated to corporate firms and TE should be positive as indicated in the literature which affirms that groups have relatively higher productivity and superior competitiveness with respect to individual firms (Becchetti, 2003) (i.e. the expected sign is negative).

The effect of firm size on efficiency is ambiguous since empirical evidence does not suggest a strong link between efficiency and firm size in either direction. "While a positive effect may be expected on the grounds of scale of economies, firm size may be negatively linked to efficiency if large firms experience management and supervision problems" (Assefa and Matambalya, 2002: 20). $\underline{\text { On }}$ the other side, Jha et al. (1998) find that large firm size is associated with higher technical as well as allocative efficiency.

Finally, dummy variables for the Italian macro area are also included to control for regional differences due to different level of development; Pavitt dummies are included because an industrial sector may have, in principle, a different production function from others; and temporal dummies are included to take into account technological progress. The expected sign for firms located in the centre or the north Italy is negative since those firms should be more efficient than firms located in the south. For the time dummy, the expected sign for the parameter is negative because, if there is technological progress, inefficiency should decrease. 


\section{Variables and descriptive statistics}

For this analysis, the VII (1995-1997), VIII (1998-2000) and IX (2001-2003) surveys of manufacturing firms by the MCC were used. The database has been published every three years since 1968 .

The survey provides a great deal of information about the production and financial indicators of Italian manufacturing firms. In the last survey, the database considers a stratified sample of 3,452 Italian manufacturing firms. The sample is stratified according to industry, geographical and dimensional distribution for firms from 11 to 500 employees. It is by census for firms with more than 500 employees.

The database contains questionnaire information regarding the individual firms' structure and behaviour, three years of balance sheet data, additional data on employees, employees' education, age of the firm, turnover, etc. Information relating to ICT expenditure has only been present since 1995, is displayed on a three-year level (1995-1997, 1998-2000 and 2001-2003) and total annual investment is provided. However, data on the stock of ICT capital are not provided. Also the variable for employees' education is displayed as one value for three years.

Table 1 analyses the ICT variable in the last three surveys. For example, in the IX survey (2001-2003), of over 3,452 firms, 591 did not invest in ICT, 253 firms said that they had invested in ICT in those three years but did not reply to the question "How much money did you invest on average in the last three years?" and 497 firms did not answer either question. 
[Insert Table 1 about here]

Following the method of Becchetti et al. (2003), who used the same data source (seventh survey), both models are estimated with the variables expressed as three year averages. Due to the fact that the ICT investment variable is expressed as a three year value. Turnover was deflated by an implicit price production deflator $(2000=100)$ and capital, raw materials and ICT investments are deflated by an implicit investment deflator $(2000=100)$.

The dependent variable is the firms' turnover, the proxy used for labour is the number of employees and the proxy for capital is the sum of fixed assets and immaterial assets. To choose these variables as proxies of output, capital and labour is quite common in previous works using the same survey (see for example: Becchetti et al., 2003; Gambardella and Torrisi, 2001; Bugamelli and Pagano, 2004).

\section{Results and discussions}

\section{ICT investments and technical efficiency}

The parameters of the stochastic frontier production function are estimated using the asymptotically efficient maximum likelihood method by FRONTIER $4.1^{4}$. The results regarding the impact of ICT investments on technical efficiency specified in equations 1-3 are presented in table 2. Both models (Cobb-Douglas

\footnotetext{
4 The FRONTIER 4.1 package uses the three steps estimation method procedure. These three steps provide a maximum likelihood estimate of the parameters of the stochastic frontier production function. The first step is an Ordinary Least Squares estimate of the function. Here all the estimators $\beta$, with the exception of the intercept $\beta_{0}$, will be unbiased. In the second step, a grid search on $\gamma$ is conducted. The value for the parameters $\beta$ (excepting $\beta_{0}$ ) are set to the OLS value, $\beta_{0}$ and $\sigma^{2}$ parameters are adjusted and all other parameters $(\mu, \eta$ and $\delta$ ) are set to zero. In the final step, the values in the grid search are used as starting values in an iterative procedure to obtain the maximum likelihood estimates.
} 
and Translog) presented in the previous section are estimated as a cross-section of the period 2001-2003 and as an unbalanced panel of 12,629 firms (observations) present in the VII, VIII and IX surveys provided by the MCC. This is done in order to compare the results and to check for sample selections issues. The sign and the significance of the variables between the two models, panel frontier and stochastic frontier, are not different.

[Insert Table 2 about here]

To test whether the Cobb-Douglas production function is an adequate representation of the data, given the specification of the translog model, the likelihood ratio test was used. The purpose of this is to test the null hypothesis that the second order coefficients of the translog frontier are simultaneously zero: $H_{0}=\beta_{i j}=0$ for all $i \leq j=1,2,3$.

The value of the generalised likelihood-ratio statistics for testing null hypothesis for the panel frontier in the case of the complete translog production function is computed in the following way:

$$
L R=2(-19256.468+20038.2)=1563.464
$$

Thus the null hypothesis that the Cobb-Douglas frontier is an adequate representation of the data is rejected, given the specification of the stochastic frontier. In other words, using a likelihood ratio test, the translog functional form is found to be a more appropriate fit for the data ${ }^{5}$.

All beta coefficients in the Cobb-Douglas production function are significantly positive, confirming that each factor contributes positively to production. The

\footnotetext{
${ }^{5}$ The likelihood ratio test is equal to: $(2 *($ Unrestricted-Restricted $))$ and follows a chi-squared distribution.
} 
joint significance of the inefficiency variables is confirmed by again using a likelihood ratio test.

The coefficient estimates for the ICT investment is always significantly negative with a $1 \%$ significance level, which indicates that more ICT investments have a negative effect on inefficiency (i.e., a positive effect on efficiency). Therefore, the null hypothesis is never rejected. This implies that ICT investments have a positive effect on the technical efficiency of the Italian manufacturing industry. This finding is consistent with the previous literature (Gholami et al., 2004; Shao and Lin, 2002).

Other control variables give the expected results. Firms located in the North (east and west) and in the Centre and firms affiliated to corporate firms are significantly more efficient than the average. This is consistent with the results of Atzeni and Carboni (2001) and Becchetti et al. (2003). In other words, firms situated in the north or centre of Italy, which are more industrialised areas, are, on average, more efficient than firms situated in South of Italy.

Despite Jha et al. (1998) results asserting that large firm in agriculture sector in India are with higher technical and allocative efficiency, in this paper small and medium size firms and firms operating in the first three Pavitt sectors are significantly more efficient than the average. This may be attributed to the specific characteristics of the Italian manufacturing sector. In fact, almost all firms are of small-medium dimensions and tend to be concentrated in the first Pavitt sector.

Results show, moreover, that older firms are significantly more efficient than the average. This supports the theory (Assefa and Matambalya, 2002) that firms 
become more efficient over time as a result of a growing stock of experience in the production process.

Mean efficiency is 0.49 which implies that output could, theoretically, be increased. This could be ascribed to the fact that ICT investments are still a small proportion of total investments (22\%). This partially confirms David's (1990) hypothesis which states that new technologies have to reach a spread rate of $50 \%$ for their beneficial effects to show.

The individual coefficients for the Cobb-Douglas model are elasticities and, thus, can be directly interpreted. In the case of the translog model, the elasticities at the mean levels of output are functions of parameters and level of explanatory variables, and, thus, individual coefficients cannot be directly interpreted as elasticities. The translog elasticities are calculated in the following way, respectively, for capital, labour and raw materials:

$$
\begin{array}{lll}
\frac{d Y}{d x_{1 i t}}=\beta_{1}+\beta_{4} x_{1 i t}+\beta_{7} x_{2 i t}+\beta_{8} x_{3 i t} & i=1,2, \ldots .11553 & \mathrm{t}=1,2,3 \\
\frac{d Y}{d x_{2 i t}}=\beta_{2}+\beta_{5} x_{2 i t}+\beta_{7} x_{1 i t}+\beta_{9} x_{3 i t} & i=1,2, \ldots .11553 ; & \mathrm{t}=1,2,3 \\
\frac{d Y}{d x_{3 i t}}=\beta_{3}+\beta_{6} x_{3 i t}+\beta_{8} x_{1 i t}+\beta_{9} x_{2 i t} & i=1,2, \ldots .11553 & \mathrm{t}=1,2,3
\end{array}
$$

Where $x_{1 i t}$ represents the capital of firm i at time $\mathrm{t} ; x_{2 i t}$ the labour of firm i at time $\mathrm{t}$ and $x_{3 i t}$ is the raw materials of firm $\mathrm{i}$ at time $\mathrm{t}$.

The calculated elasticities and returns to scale for the translog panel production frontier are displayed in table 3.

[Insert Table 3 about here] 
All the elasticities are positive, however returns to scale are equal to 0.84 , which implies that decreasing returns to scale were present in the Italian manufacturing sector over the period 1995-2003. This finding agrees with other works which show that, in the period considered, the Italian manufacturing sector presented decreasing returns to scale (Medda and Piga, 2004; Bonaccorsi and Granelli, 2005).

Table 4 displays mean efficiency by year. It is evident that efficiency declined in three year period 1998-2000 and increased in the next period. However, if the period 2001-2003 is compared with 1995-1997, average efficiency decreased. This result confirms the previous findings of decreasing returns to scale. In fact, if a firm has experienced a decrease in inefficiency, it may use the same input to produce more output or produce the same amount of output with less input.

[Insert Table 4 about here]

\section{Unbalanced panel and attrition}

With a balanced panel, the same units appear in each time period. Conversely, with an unbalanced panel some units do not appear in every time period. If the reason a firm leaves the sample (attrition) is correlated with the idiosyncratic error, then the resulting sample section problem may cause biased estimators (Wooldridge, 2002).

In other words, unbalanced panel data may arise for several reasons (i.e. rotating panel, incidental truncation). A "problem arises when attrition from a panel is due to units electing to drop out. If this decision is based on factors that are systematically related to the response variable, even after we condition on 
explanatory variables, a sample selection problem can result" (Wooldridge, 2002: 578).

In order to check whether selection is an issue in this paper the balanced panel data is estimated and a selection indicator is added to the unbalanced panel data. The results for the balanced panel data estimations are presented in table 5 .

[Insert Table 5 about here]

The sign and the significance of variables are not different from the unbalanced panel data. The coefficient estimates for ICT investments is always significantly negative with a $1 \%$ significance level, which indicates that more ICT investments have a negative effect on inefficiency. Therefore, in this case too, the hypothesis that ICT investments are able to increase technical efficiency is not rejected. All the other variables are of the expected sign and the interpretation is the same as before. The Cobb-Douglas panel frontier is rejected in favour of the translog panel frontier.

Table 6 presents the results for elasticities, returns to scale and efficiency by year for the translog complete model.

[Insert Table 6 about here]

The results for the calculated elasticities and returns to scale are similar to the previous estimation. In fact, the elasticities are all positive and the returns to scale are equal to 0.81 , which confirms the previous finding that decreasing returns to scale were present in the Italian manufacturing sector over the period 1995-2003.

The only difference with the unbalanced panel is that, in this case, the efficiency scores by year were also increasing over the 2 time periods 1995-1997 
and 1998-2000. However, in this case too, mean efficiency is 0.51 which implies that output could theoretically have increased.

The second step of the attrition analysis is to construct the selection indicator. The selection indicator assumes a value of 0 for firms that are always present in the panel and for attriters the selection indicator is equal to 1 in the period just before attrition (Wooldridge, 2002).

The selection indicator is included in the production function and in the efficiency equation (and given separately to make sure identification is not an issue). The results are displayed in Table 7. In this case the null hypothesis is that: $u_{i t}$ is uncorrelated with $s_{i t}$ for all periods, where $s_{i t}$ represents the selection indicators. In no cases can the null hypothesis be rejected, so it is possible to conclude that selection is not a problem in this sample.

[Insert Table 7 about here]

\section{Conclusion}

The impact of ICT investments on firm performance was a highly debated topic after Solow's assertion that "You can see the computer age everywhere but in the productivity statistics". A lot of economists referred to this assertion as "the productivity paradox".

The productivity paradox seemed to be solved after Brynjolfsson and Hitt (1996) presented their significant firm-level empirical evidence. In fact, recent studies have been able to show the positive relation between ICT investments and productivity, and consequently, end the controversy over the ICT productivity 
paradox. Our results confirm that the paradox no longer stands for Italian manufacturing firms either.

In this work, the impact of ICT technologies on technical efficiency is analysed using an unbalanced panel of data (1995-2003) on Italian manufacturing firms. The data utilised were the VII, VIII and IX surveys by the MCC.

Compared to the existing empirical literature on the role of ICT investments at firm level, this work deals with the functional form to be used in modelling the impact of ICT on technical efficiency. Not many studies have considered economic performance measures like the technical efficiency of the production process in the area of ICT. However, this methodology may be interpreted as another way to explain the productivity paradox given the close relationship between productivity and technical efficiency.

As far as functional form is concerned, both the Cobb-Douglas and the translog production function frontier were used because the translog is more flexible than the Cobb-Douglas. The results support this choice, since the assumption inherent in the technology of a Cobb Douglas was rejected in all models. Moreover, the literature on ICT investments to which this work refers generally omits testing of the suitability of the Cobb-Douglas specification.

Our results indicate that information and communication technology investments have a positive and significant effect on technical efficiency in the production process of Italian manufacturing firms. In fact, the coefficient of ICT investments is significantly negative, which indicates that, if ICT investments increase, Italian manufacturing firms tend to have lower values of inefficiency effects i.e. higher efficiency. 
Other control variables used in the inefficiency equation give expected results. Firms located in the North and in the Centre and firms affiliated to corporate groups are significantly more efficient than the average. Moreover older firms are significantly more efficient than the average.

Mean efficiency is 0.49 which implies that output could theoretically be increased. This may be ascribed to the fact that ICT investments are still a small proportion of total investments (22\%). This partially confirms David's hypothesis (1990), which states that new technologies have to reach a spread rate of $50 \%$ for their positive effects to show.

However, it should be noted that investments in technological capital are not the only way to achieve higher growth; other factors might be the positive externalities due to the ICT investment growth in some sectors, human capital and/or structural changes in different sectors.

\section{References}

Albert, M. G. (1998) Regional technical efficiency: a stochastic frontier approach, Applied Economics Letters, 5, 723-726.

Arestis, P., Chortareas, G. and Desli, E. (2006) Technical Efficiency and Financial Deepening in the non-OECD Economies, International Review of Applied Economics, 20, 3, 353-373.

Arvanitis, S. (2004) Information Technology, Workplace Organisation, Human Capital and Firm Productivity: Evidence for the Swiss Economy, in The Economic Impact of ICT - Measurement, Evidence and Implications, OECD, Paris. 
Assefa, A. and Matambalya, F. A. S. T. (2002) Technical Efficiency of Small and Medium-Scale Enterprises, EASSRR, XVIII, 2.

Atzeni, G. and Carboni, O. A. (2001) The Economic Effects of Information Technology: Firm Level Evidence from the Italian Case, CRENoS, Working Paper.

Basu, S., Fernald, J. G., Oulten, N. and Srinivan, S. (2003) The case of the missing productivity growth: or, does information technology explain why productivity accelerated in the United States but not the United Kingdom?, NBER, Working Paper series 10010.

Battese, G. E. and Coelli, T. J. (1995) A model for technical efficiency effect in a stochastic frontier production functions for panel data, Empirical Economics, 20, 325-332.

Becchetti, L., Londono Bedoya, D. A. and Paganetto, L. (2003) ICT Investment, Productivity and Efficiency: Evidence at Firm Level Using a Stochastic Frontier Approach, Journal of Productivity Analysis, 20, 143-167.

Bonaccorsi, A. and Granelli, A. (2005) L'intelligenza s'industria. Creatività e innovazione per un nuovo modello di sviluppo, Il Mulino, Bologna.

Bresnahan, T. F. and Trajtenberg, M. (1995) General Purpose Technologies: 'Engines of Growth'?, Journal of Econometrics, Special Issue, 65, 83-108.

Brynjolfsson, E. and Hitt, L. (1996) Paradox lost? Firm-level evidence on the returns to information systems spending, Management Science, 42, 541-558.

Brynjolfsson, E. and Hitt, L. (2000) Beyond computation: Information Technology, Organization Transformation and Business Performance, Journal of Economic Perspectives, 14, 23-48. 
Bugamelli, M. and Pagano, P. (2004) Barriers to Investment in ICT, Applied Economics, 36, 2275-2286.

Carroll, J., Newman, C. and Thorne, F. (2007) Understanding the Factors that Influence Dairy Farm Efficiency in the Republic of Ireland, RERC Working Paper Series 07-WP-RE-06.

Castiglione, C. (2006) Nuove tecnologie e crescita nell'Unione Europea”, in Crescita e Prospettive dell'Unione Europea allargata (Ed.) D. Infante, Il Mulino, Bologna, pp. 225-271.

Castiglione, C. (2008) The impact of Information and Communication Technology on Italian manufacturing firms, Journal of Postgraduate Research, Trinity College Dublin, 7, 136-152.

Coelli, T., Rao, D. S. P. and Battese, G. E. (1998) An Introduction to Efficiency and Productivity Analysis, Norwell, MA: Kluwer Academic Publishers.

Engelbrecht, H. and Xayavong, V. (2006) ICT intensity and New Zealand's productivity malaise: Is the glass half empty or half full?, Information Economic and Policy, 18, 24-42.

Farrell, M. J. (1957) The measurement of productive efficiency, Journal of the Royal Statistical Society, 120, 253-281.

Gambardella, A. and Torrisi, S. (2001) Nuova industria o nuova economia? L'impatto dell'informatica sulla produttività dei settori manifatturieri in Italia, Moneta e Credito, 213, 39-76

Gholami, R., Moshiri, S. and Lee, S. Y. T. (2004) ICT and Productivity of the Manufacturing Industries in Iran", Electronic Journal on Information System in Developing Countries, 19, 1-19. 
Gilchrist, S., Gurbaxani, V. and Town, R. (2001) Productivity and the PC Revolution, CRITO.

Gordon, R. J. (2000) Does the New Economy Measure Up to the Great Inventions of the Past?, Journal of Economic Perspective, 14, 49-74.

Gordon, R. J. (2002) Technology and Economic Performance in the American Economy, NBER Working Paper series 8771.

Helpman, E., Trajtenberg, M. (1996), "Diffusion of General Purpose Technologies", NBER wp nr. 5773

Infante, D. (1990) Produzione, fattori e progresso tecnico nell'industria manifatturiera italiana (1973-1984), L'Industria, 1, 49-78.

Jha, R., Chitkara, P. and Gupta, S. (1998) Productivity, technical and allocative efficiency and farm size in wheat farming in India: a DEA approach, Applied Economics Letters, 7, 1-5.

Jorgenson, D. W. (2001) Information technology and the U.S. economy, American Economic Review, 91, 1-32.

Jorgenson, D. W. and Stiroh, K. J. (2000) U.S. Economic Growth at the Industry Level”, American Economic Review, 90, 161-167.

Jovanovic, B. and Rousseau, P. L. (2005) General Purpose Technologies, NBER Working Papers series 11093.

Kenneth, L. K. and Dedrick, J. (1994) Payoffs from Investment in Information Technology: Lessons from the Asia-Pacific Region, World Development, 22, $1921-1931$.

Medda, G. and Piga, C. (2004) R\&S e Spillover industriali: un'analisi sulle imprese italiane, CRENOS. 
Odeck, J. (2007) Measuring technical efficiency and productivity growth: a comparison of SFA and DEA on Norwegian grain production data, Applied Economics, 39, 2617-2630.

Oliner, S. D. and Sichel, D. E. (2000) The Resurgence of Growth in the Late 1990s: Is Information Technology the Story?, Journal of Economic Perspectives, 14, 3-22.

O'Mahony, N. and Ark, V.B. (2003), CD-ROM: http://www.ggdc.net/dseries/60industry.shtml.

Pilat, D. (2004) The ICT Productivity Paradox: Insights from Micro Data, OECD Economic Studies, 1, 37-65.

Schmidt, P. and Sickles, R. C. (1984) Production Frontiers and Panel Data, Journal of Business and Economic Statistics, 2, 299-326.

Schreyer, P. (2000) The contribution of information and communication technology to output growth: a study of the G7 countries, STI Working Paper Z, OECD, Paris.

Seiford, L. M. (1996) Data envelopment analysis: the evolution of the state of the art (1978-1995), Journal of Productivity Analysis, 7, 99-137.

Shao, B. B. M. and Lin, W. T. (2001) Measuring the value of information technology in technical efficiency with stochastic production frontiers, Information and Software Technology, 43, 447-456.

Shao, B. B. M. and Lin, W. T. (2002) Technical efficiency analysis of information technology investments: a two-stage empirical investigation, Information and Management, 39, 391-401.

Solow, R. M. (1987) We'd better watch out, New York Review of Books, 12, 36. 
Stiroh, K. J. (2000) Investment and Productivity Growth A Survey from the Neoclassical and New Growth Perspectives, Canada, Working Paper n. 24.

Wooldridge, J.M. (2002), Econometric analysis of cross section and panel data, MIT, Cambridge. 
Fig. 1: The Production Frontier

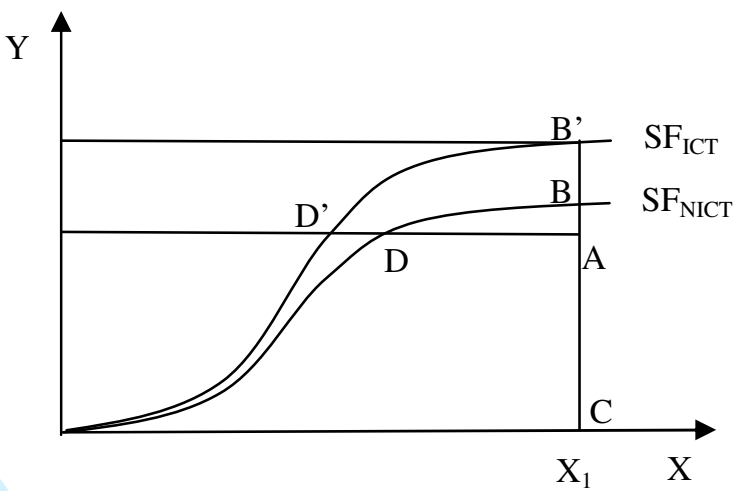


Table 1 - Number of firms surveyed

\begin{tabular}{|l|c|c|c|c|}
\hline & 1995-1997 survey & $1998-2000$ survey & 2001-2003 survey & All periods \\
\hline Observations & 4497 & 4680 & 3452 & 514 \\
Firms that invested in ICT & 2984 & 3480 & 2111 & 291 \\
Firms that invested but did not indicate the amount & 128 & 156 & 253 &.. \\
Firms that did not invest in ICT & 975 & 851 & 497 & 22 \\
Firms that did not answer the questions about ICT & 410 & 193 &.. \\
investments & & & \\
\hline
\end{tabular}


Table 2 - Cobb-Douglas and translog production frontier with ICT investments as a specific factor of production (t-statistics in parenthesis)

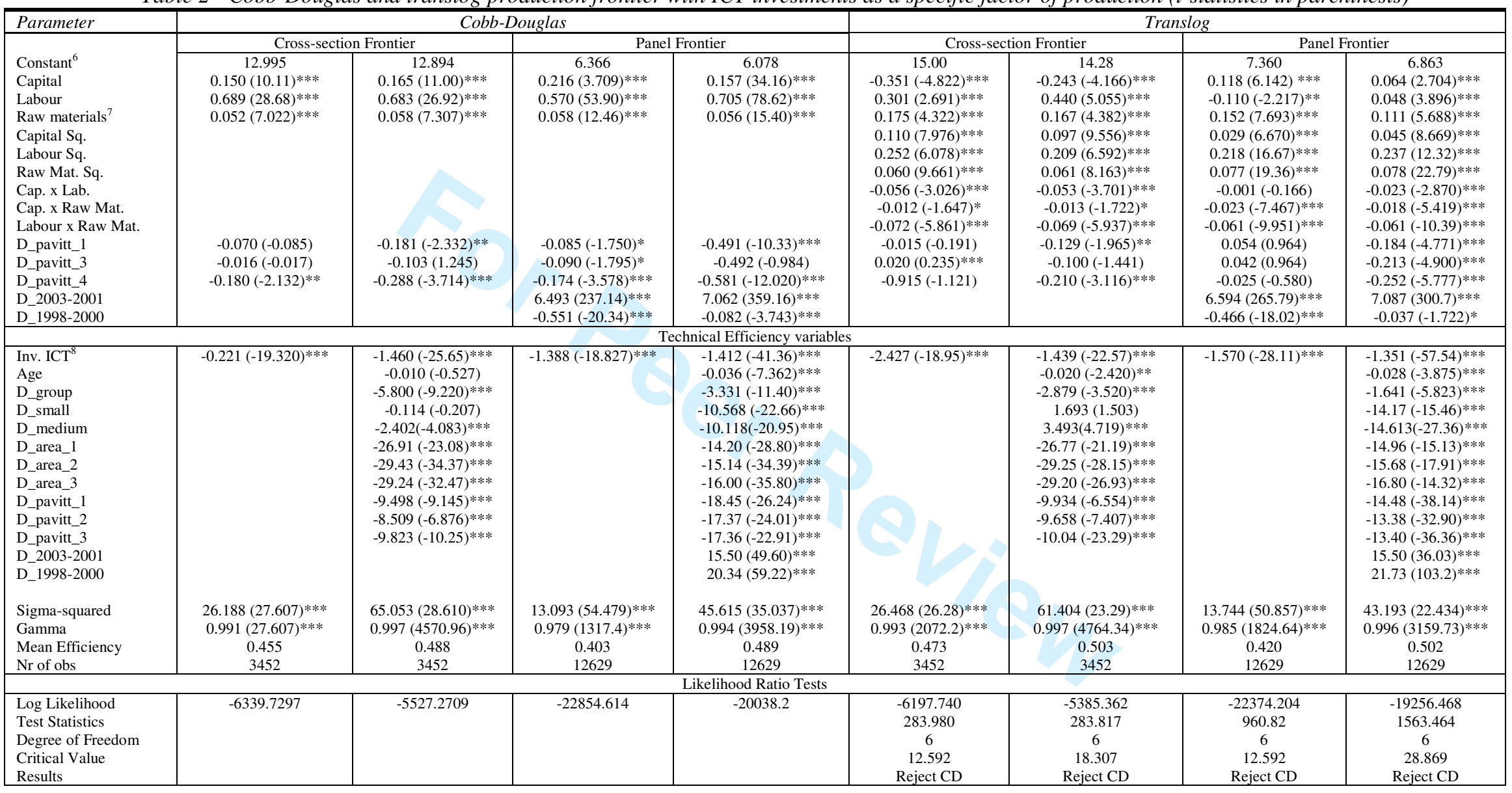

\footnotetext{
$6 * * *$ indicates significance of $1 \%, * *$ at $5 \%$ and $*$ at $10 \%$.

${ }^{7}$ Before taking the logs, 1 was summed to raw materials since there were some firms with 0 values for these variables.

${ }^{8}$ Since there were some firms that did not invest in ICT before taking the logs 1 was summed to the investment in ICT
} 
Table 5 - Cobb-Douglas and translog production frontiers with ICT investments as a specific factor of

Table 4 - Descriptive Statistics of Efficiency Scores by Year (Translog complete model)

\begin{tabular}{|c|c|c|c|}
\hline Variable & Obs & Mean & Std. Dev. \\
\hline $1995-1997$ & 11553 & 0.561 & 0.178 \\
$1998-2000$ & 11553 & 0.438 & 0.235 \\
$2001-2003$ & 11553 & 0.511 & 0.197 \\
\hline
\end{tabular}

Table 3 - Descriptive statistics of elasticities and returns to scale (translog complete model)

\begin{tabular}{|c|c|c|c|}
\hline Variable & Obs & Mean & Std. Dev. \\
\hline Capital & 11553 & 0.212 & 0.054 \\
Labour & 11553 & 0.487 & 0.192 \\
Raw materials & 11553 & 0.139 & 0.176 \\
Returns to Scale & 11553 & 0.838 & 0.171 \\
\hline
\end{tabular}

\begin{tabular}{|c|c|c|c|c|}
\hline Parameter & \multicolumn{4}{|c|}{ Balanced Panel Frontier } \\
\hline & \multicolumn{2}{|c|}{ Cobb-Douglas Panel Frontier } & \multicolumn{2}{|c|}{ Translog Panel Frontier } \\
\hline Constant $^{9}$ & 6.027 & 5.579 & 7.588 & 7.360 \\
\hline Capital & $0.169(10.03)^{* * *}$ & $0.132(8.75)^{* * *}$ & $0.021(3.248)^{* * * *}$ & $-0.344(5.303)^{* * *}$ \\
\hline Labour & $0.656(23.07)^{* * *}$ & $0.736(28.91)^{* * *}$ & $0.021(1.603)$ & $0.047(3.492)^{* * *}$ \\
\hline Raw materials ${ }^{10}$ & $0.058(5.45)^{* * *}$ & $0.059(6.12)^{* * *}$ & $-0.007(1.115)$ & $0.039(6.674)^{* * * *}$ \\
\hline Capital Sq. & & & $0.031(1.96)^{* *}$ & $0.040(2.456)^{* * *}$ \\
\hline Labour Sq. & & & $0.100(3.39)^{* * *}$ & $0.147(3.609)^{* * * *}$ \\
\hline Raw Mat. Sq. & & & $0.058(6.10)^{* * *}$ & $0.060(6.512)^{* * * *}$ \\
\hline Cap. x Lab. & & & $0.006(3.135)^{* * * *}$ & $-0.001(-0.920)$ \\
\hline Cap. x Raw Mat. & & & $-0.016(-1.588)^{* * *}$ & $-0.013(-1.400)$ \\
\hline $\begin{array}{l}\text { Lab. X Raw } \\
\text { Mat. }\end{array}$ & & & $-0.008(-4.321)^{* * *}$ & $-0.026(-1.350)$ \\
\hline D_pavitt_1 & $-0.107(-0.629)$ & $-0.233(-1.76)^{*}$ & $0.133(0.964)$ & $-0.131(-1.080)$ \\
\hline D_pavitt_3 & $-0.088(-0.508)$ & $-0.053(-0.383)$ & $0.136(0.996)$ & $-0.054(-4.254) * * *$ \\
\hline D_pavitt_4 & $-0.170(-1.003)$ & $-0.236(-1.723)^{*}$ & $0.097(0.715)$ & $-0.102(-0.805)$ \\
\hline D_2003-2001 & $6.557(114.60)^{* * *}$ & $7.072(137.98)^{* * * *}$ & $6.581(125.81)^{* * *}$ & $6.955(141.7)^{* * * *}$ \\
\hline \multirow{2}{*}{ D_1998-2000 } & $-0.239(-9.36)^{* * *}$ & $-0.022(-3.743) * * *$ & $-0.226(-4.218)^{* * *}$ & $-0.011(-2.211)^{* *}$ \\
\hline & \multicolumn{4}{|c|}{ Technical Efficiency variables } \\
\hline Inv. $\mathrm{ICT}^{11}$ & $-1.139(-9.358)^{* * *}$ & $-1.019(-13.99) * * *$ & $-1.321(-10.06)^{* * *}$ & $-0.671(-10.61)^{* * *}$ \\
\hline Age & & $-0.065(-7.507)^{* * *}$ & & $-0.068(-10.063)^{* * *}$ \\
\hline D_group & & $0.862(0.138)$ & & $-1.350(-2.498)^{* *}$ \\
\hline D_small & & $-1.292(-2.00)^{* *}$ & & $-6.136(-7.139) * * *$ \\
\hline D_medium & & $-2.215(-3.51) * * *$ & & $-10.784(-11.727)^{* * *}$ \\
\hline D_area_1 & & $-4.53(-6.07) * * *$ & & $-7.013(-10.217) * * *$ \\
\hline D_area_2 & & $-8.47(-10.22)^{* * *}$ & & $-12.381(-14.40)^{* * *}$ \\
\hline D_area_3 & & $-9.98(-14.02)^{* * *}$ & & $-13.99(-14.42)^{* * *}$ \\
\hline D_pavitt_1 & & $-8.24(-5.93)^{* * *}$ & & $-12.41(-9.18)^{* * *}$ \\
\hline D_pavitt_2 & & $-1.198(0.92)$ & & $-5.00(-3.290)^{* * *}$ \\
\hline D_pavitt_3 & & $-7.21(-5.26) * * *$ & & $-10.03(-6.153) * * *$ \\
\hline D_2003-2001 & & $16.26(28.97)^{* * * *}$ & & $-7.79(-12.46)^{* * *}$ \\
\hline D_1998-2000 & & $9.28(-10.77)^{* * *}$ & & $9.28(-10.77)^{* * *}$ \\
\hline Sigma-squared & $8.289(16.597) * * *$ & $25.943(11.379) * * *$ & $8.547(16.855)^{* * *}$ & $26.330(22.434)^{* * *}$ \\
\hline Gamma & $0.973(367.2) * * *$ & $0.992(1099.90)^{* * *}$ & $0.978(446.69)^{* * *}$ & $0.994(1580.65)^{* * *}$ \\
\hline Mean Efficiency & 0.485 & 0.574 & 0.503 & 0.580 \\
\hline \multirow[t]{2}{*}{$\mathrm{Nr}$ of obs } & 1542 & 1542 & 1542 & 1542 \\
\hline & \multicolumn{4}{|c|}{ Likelihood Ratio Tests } \\
\hline Log Likelihood & -22854.614 & -20038.2 & -2341.86 & -1939.39 \\
\hline Test Statistics & & & 57.33 & 107.78 \\
\hline Degree of Freed. & & & 6 & 6 \\
\hline Critical Value & & & 12.592 & 28.869 \\
\hline Results & & & Reject CD & Reject CD \\
\hline
\end{tabular}

9*** indicates significance of $1 \%, * *$ at $5 \%$ and $*$ at $10 \%$.

${ }^{10}$ Before taking the logs 1 was summed to raw materials since there were some firms with 0 values for these variables.

${ }^{11}$ Since there were some firms that did not invest in ICT before taking the logs 1 was summed to the investment in ICT. 
Table 6 - Descriptive statistics of elasticities, returns to scale and efficiency scores by year (translog complete model-balanced panel data)

\begin{tabular}{|c|c|c|c|c|c|}
\hline \multicolumn{2}{|c|}{ Elasticities and returns to scale } & \multicolumn{3}{|c|}{ Efficiency scores by year } \\
\hline Variable & Mean & Std. Dev. & Year & Mean & \\
Capital & 0.183 & 0.053 & & 0.446 & 0.166 \\
Labour & 0.484 & 0.116 & $1995-1997$ & 0.509 & 0.148 \\
Raw materials & 0.140 & 0.135 & $1998-2000$ & 0.586 & 0.162 \\
Returns to Scale & 0.806 & 0.201 & $2001-2003$ & 0 \\
\hline
\end{tabular}

Table 7 - Translog production frontier with selection indicator (t-statistics in parenthesis)

\begin{tabular}{|c|c|c|c|}
\hline Parameter & \multicolumn{3}{|c|}{ Translog } \\
\hline & Production Frontier & $\begin{array}{c}\text { Unbalanced Panel } \\
\text { Frontier }\end{array}$ & $\begin{array}{l}\text { Production Frontier } \\
\text { And } \\
\text { Efficiency Equations }\end{array}$ \\
\hline Constant $^{12}$ & 6.989 & 6.992 & 6.992 \\
\hline Capital & $0.060(3.082)^{* * *}$ & $0.060(3.246)^{* * *}$ & $0.118(6.142)^{* * *}$ \\
\hline Labour & $0.011(2.326)^{* *}$ & $0.036(8.575)^{* * * *}$ & $0.060(3.189) * * *$ \\
\hline Raw materials ${ }^{13}$ & $0.113(6.653)^{* * *}$ & $0.111(6.170)^{* * *}$ & $0.011(2.616)^{* * *}$ \\
\hline Capital Sq. & $0.045(8.490)^{* * *}$ & $0.045(8.879)^{* * *}$ & $0.111(6.616) * * *$ \\
\hline Labour Sq. & $0.243(19.62)^{* * * *}$ & $0.243(20.50)^{* * * *}$ & $0.045(9.599)^{* * * *}$ \\
\hline Raw Mat. Sq. & $0.077(24.67)^{* * *}$ & $0.078(24.21)^{* * *}$ & $0.243(20.26)^{* * *}$ \\
\hline Cap. x Lab. & $-0.021(-4.021)^{* * *}$ & $-0.021(-4.158) * * *$ & $0.078(22.57)^{* * *}$ \\
\hline Cap. x Raw Mat. & $-0.018(-5.253) * * *$ & $-0.018(-5.487)^{* * *}$ & $-0.021(-4.001)^{* * *}$ \\
\hline Lab. X Raw Mat. & $-0.061(-11.03) * * *$ & $-0.061(-11.07)^{* * *}$ & $-0.018(-5.746)^{* * *}$ \\
\hline D_pavitt_1 & $-0.185(-4.552)^{* * * *}$ & $-0.188(-4.463) * * *$ & $-0.187(-4.344) * * *$ \\
\hline D_pavitt_3 & $-0.213(-5.400)^{* * *}$ & $-0.217(5.016)^{* * *}$ & $-0.216(-4.919) * * *$ \\
\hline D_pavitt_4 & $-0.248(-6.002) * * *$ & $-0.251(-5.847)^{* * *}$ & $-0.251(-5.853)^{* * *}$ \\
\hline D_2003-2001 & $7.089(265.4)^{* * *}$ & $7.082(379.9)^{* * *}$ & $7.088(275.01)^{* * * *}$ \\
\hline D_1998-2000 & $-0.040(-1.837)^{*}$ & $-0.040(-2.033)^{* *}$ & $-0.040(-1.864)^{* * *}$ \\
\hline \multirow[t]{2}{*}{ Selection Indicator } & $0.010(0.503)$ & & $0.008(0.415)$ \\
\hline & \multicolumn{3}{|c|}{ Technical Efficiency variables } \\
\hline Inv. $\mathrm{ICT}^{14}$ & $-1.412(-35.06)^{* * * *}$ & $-1.387(-32.82)^{* * *}$ & $-1.398(-49.25)^{* * *}$ \\
\hline Age & $-0.031(-6.495)^{* * * *}$ & $-0.031(-6.756)^{* * *}$ & $-0.031(-5.891)^{* * *}$ \\
\hline D_group & $-1.972(-7.522)^{* * *}$ & $-1.966(-7.455) * * *$ & $-1.992(-7.202)^{* * *}$ \\
\hline D_small & $-13.30(-29.53)^{* * * *}$ & $-13.37(-24.89)^{* * * *}$ & $-13.40(-22.70)^{* * *}$ \\
\hline D_medium & $-14.27(-29.04)^{* * *}$ & $-14.36(-33.39) * * *$ & $-14.40(-29.19)^{* * *}$ \\
\hline D_area_1 & $-14.01(-28.45)^{* * *}$ & $-13.97(-34.30) * * *$ & $-13.92(-27.54) * * *$ \\
\hline D_area_2 & $-14.75(-30.80) * * *$ & $-14.71(-36.65)^{* * *}$ & $-14.68(-31.67) * * *$ \\
\hline D_area_3 & $-15.68(-37.90)^{* * *}$ & $-15.67(-45.04)^{* * *}$ & $-15.63(-31.71)^{* * *}$ \\
\hline D_pavitt_1 & $-15.50(-27.75)^{* * *}$ & $-15.46(-28.01)^{* * *}$ & $-15.40(-21.50)^{* * *}$ \\
\hline D_pavitt_2 & $-14.64(-24.75)^{* * *}$ & $-14.68(-21.79)^{* * *}$ & $-14.61(-20.14)^{* * *}$ \\
\hline D_pavitt_3 & $-14.52(-26.34)^{* * *}$ & $-14.51(-22.29)^{* * *}$ & $-14.44(-19.99)^{* * *}$ \\
\hline D_2003-2001 & $15.23(42.36) * * *$ & $15.05(48.65)^{* * *}$ & $15.08(37.31)^{* * *}$ \\
\hline D_1998-2000 & $21.59(91.81)^{* * *}$ & $21.62(94.89)^{* * *}$ & $21.60(96.51)^{* * *}$ \\
\hline Selection Indicator & & $-0.176(-0.740)$ & $-0.153(-0.471)$ \\
\hline Sigma-squared & $43.92(38.27)^{* * *}$ & $43.97(39.81)^{* * *}$ & $43.96(38.38)^{* * *}$ \\
\hline Gamma & $0.996(5958.2)^{* * *}$ & $0.996(6191.20)^{* * *}$ & $0.996(6189.9)^{* * *}$ \\
\hline Mean Efficiency & 0.50 & 0.50 & 0.50 \\
\hline $\mathrm{Nr}$ of obs & 12629 & 12629 & 12629 \\
\hline \multicolumn{4}{|c|}{ Elasticities } \\
\hline Capital & 0.21 & 0.21 & 0.21 \\
\hline Labour & 0.48 & 0.48 & 0.48 \\
\hline Raw Materials & 0.14 & 0.14 & 0.14 \\
\hline Returns to scale & 0.83 & 0.83 & 0.83 \\
\hline
\end{tabular}

$12 * * *$ indicates significance of $1 \%, * *$ at $5 \%$ and $*$ at $10 \%$.

${ }^{13}$ Before taking the logs 1 was summed to raw materials since there were some firms with 0 values for these variables.

${ }^{14}$ Since there were some firms that did not invest in ICT before taking the logs 1 was summed to the investment in ICT. 